\title{
粉砕骨折に対するチタンミニプレートを用いた頭蓋骨形成術
}

$\begin{array}{lllllllll}\text { 中 } 川 & \text { 摂 } & \text { 阿 } & \text { 部 } & \text { 雅 } & \text { 光 } & \text { 辻 } & \text { 武 } & \text { 寿 } \\ \text { 田 } & \text { 㴊 和 雄 } & \text { 後 } & \text { 藤 } & \text { 昌 } & \text { 昭* } & \text { 香 } & \text { 月 } & \text { 武* }\end{array}$

\section{Cranioplasty Using Titanium Miniplates for the Repair of a Comminuted Fracture : Report of Two Cases}

by

\section{Setsuko Nakagawa M.D., Masamitsu Abe, M.D., Takehisa Tsuji M.D., Kazuo Tabuchi, M.D., Masaaki Goto, M.D., and Takeshi Katsuki, M.D. \\ from}

Departments of Neurosurgery, and Oral and Maxillofacial Surgery, Saga Medical School

To repair simple depressed fractures of the skull, wire ligatures are usually sufficient. However, complex depressed fractures of the skull in which the bone is smashed into fragments are difficult to reconstruct by wiring. Therefore, since bone flaps tend to be fragile and may result in a deformed appearance, the authors have used bone fragments combined with titanium miniplates to repair depressed skull fracture in two cases. These miniplates were originally developed for maxillofacial surgery, and are biologically quite stable.

In the cases we describe, bone flaps that were smashed into fragments were sufficiently stabilized to resume the original cranial shape in a reconstruction using titanium miniplates. An extra advantage is that titanium miniplates rarely obscure intracranial structures on postoperative computed imaging.

The cranioplasties were successful and the patients have had a favorable postoperative course.

(Received July 29, 1993 ; accepted October 15, 1993)

Key words : titanium miniplate, cranioplasty

\section{Jpn J Neurosurg (Tokyo) 3: 259-262, 1994}

\section{はじめに}

楩没頭蓋骨骨折，特に骨片が多数となった例において は，骨片のゆがみ，骨片の粉砕よる骨量の減少のため， 通常の鋼線による固定では，外観に凹凸を生じたり，十 分な強度が得られない場合がある。このような症例に対 して, チタンミニプレートを用い良好な頭蓋骨形成が得 られたので報告する。

\section{症 例}

【症例 1】

患 者：39 歳, 男性
1990 年 12 月 13 日, 運転中に車ごと河川敷に落下し, 頭部を打撲した。搬入時, 右側頭頭頂部に皮下出血を認 めた．意識は半昏睡で GCS 6 点．瞳孔不同を認めた。 頭部 CT で左頭頂骨, 側頭骨に僣没骨折があり, 右頭頂 側頭部に硬膜下血腫を, 右側頭葉〜頭頂葉に脳内血腫を 認めた (Fig. 1A，B)。緊急に減圧開頭と硬膜下血腫除去 術を施行した。骨折部は，10 個の骨片となっており，千 タンミニプレート (Leibinger Würzburg Titanium Miniplate System, Leibinger GmbH，Germany）を用

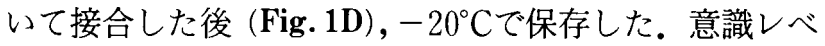
ルが上昇し, 全身状態が良好となった 1 力月後に凍結保 存骨を用いて頭蓋骨形成術を行った。術後の外観は良好

佐賀医科大学脳神経外科 $/ \overline{\mathbf{T}} 849$ 佐賀市鍋島 5-1-1〔連絡先：中川攝子〕

Address reprint requests to: Setsuko Nakagawa, M.D., Department of Neurosurgery, Saga Medical School, 5-1-1 Nabeshima,

Saga-shi, 849 Saga, Japan

*同口腔外科 

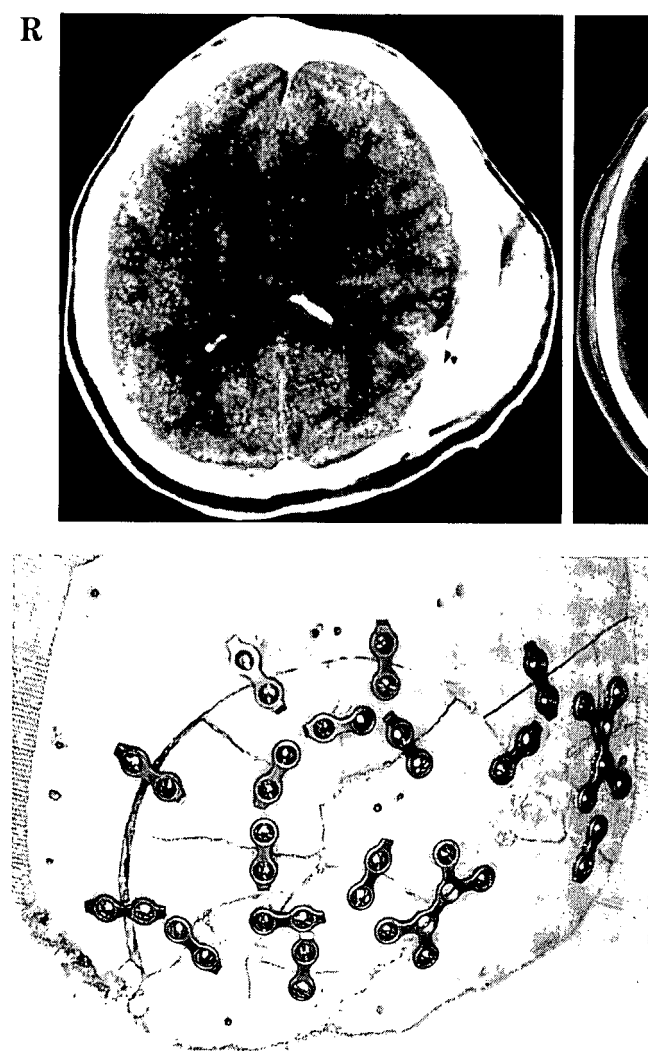
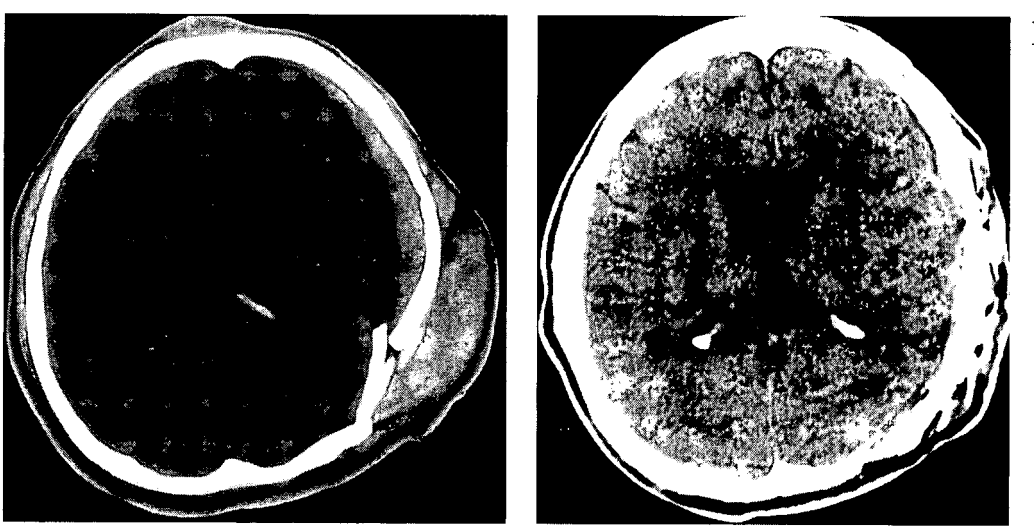

$\frac{\mathrm{A}}{\mathrm{D} \mid} \mathbf{B} \mid \mathbf{C}$
Fig. 1 Case 1

A, B : Preoperative CT scans show a depressed and comminuted fracture of the left temporo-parietal region.

C : Postoperative CT scan shows an excellent cranial shape and few artifacts.

D : The reconstruction combining bone flaps with titanium miniplates.

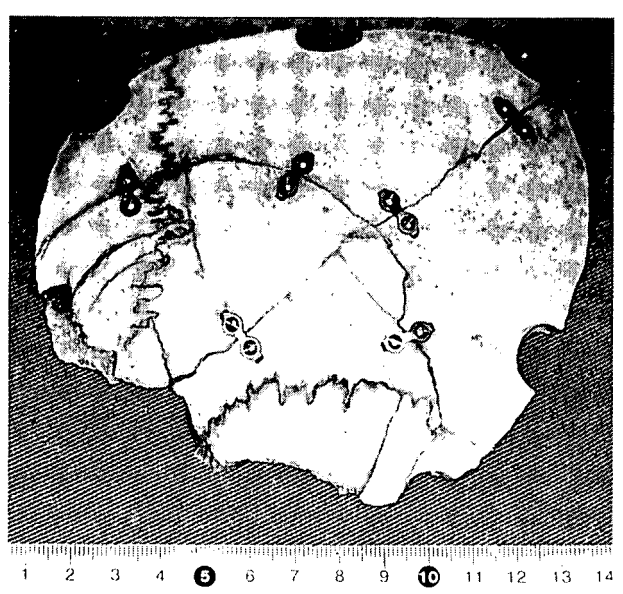

$\overline{\mathbf{A}|\mathbf{B}| \mathbf{C}}$
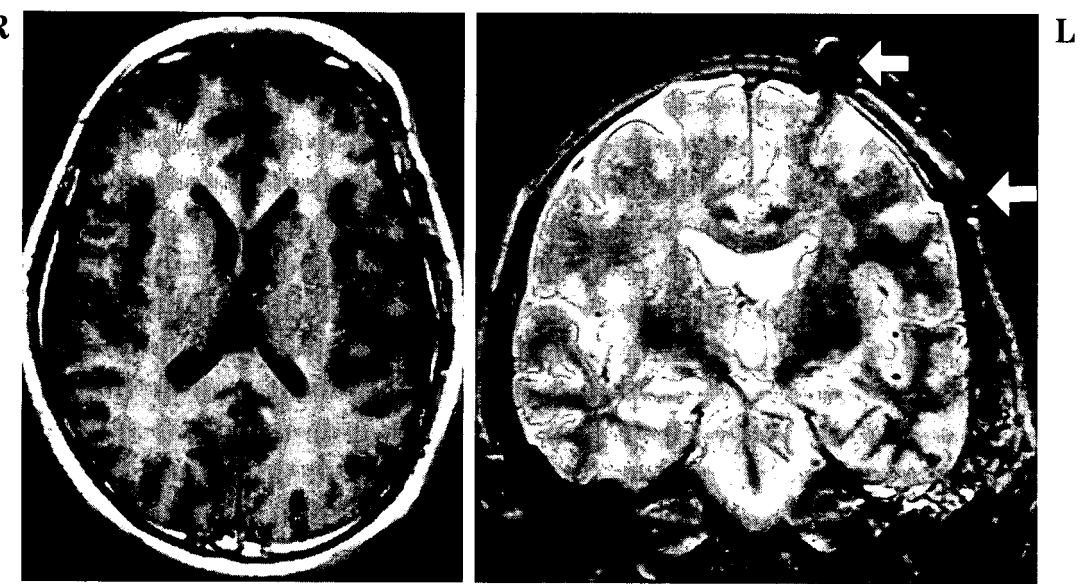

Fig. 2 Case 2

A : The reconstruction combing bone flaps with titanium miniplates

B, C : Postoperative MRIs show few artifacts about the titanium miniplates (arrows).

で，局所の炎症反応もみられなかった。術後のCTでは ミニプレートによるアーチファクトは軽度で，読影に特 に支障はなかった (Fig.1C)。

\section{【症例 2】}

\section{患 者：52 歳, 男性}

1991 年 9 月 27 日, 屋根より転落し頭部の打撲および 裂傷をきたし搬入された。意識は傾眠で左動眼神経麻痺, 左不全片麻痺を認めた。CT で左頭頂側頭骨陥没骨折を
認めた。 また, 気脳症, 硬膜外血腫, 外傷性くも膜下出 血も認めた。緊急で開頭血腫除去術, 陥没骨折整復術を 施行した。陥没骨折部は 4 個の骨片となっており, チ夕 ンミニプレートで接合した (Fig. 2A). 術後, 瞳孔不同が しばらく残存したほかには神経学的異常所見はなかっ た。術後 MRI でミニプレートによるアーチファクトは ほとんど認められなかった (Fig. 2B, C).

2 症例とも外観は良好で，十分な強度が得られた。症 例 1 は術後 2 年, 症例 2 は術後 1 年 4 力月経過している 
が，臨床経過上は問題なく，骨弁の吸収や局所の炎症等 はみられない。

\section{考察}

ミニプレートによる骨接合術は，口腔外科領域，特に 下䋶骨骨折に対して行われているが，最近，骨接合後摘 出する必要がないとされるチタン性のミニプレートがよ く用いられている223)5)6)10) 12)15) 17).チタンは生体親和 性に優れ, 屈曲適合後も生物学的環境下で安定で, 耐腐 食性を有するとされている。ミニプレートは比較的柔ら かいため，骨面への適合も容易であり，顔面骨のあらゆ る部位の骨折に使用されている。最近では䫟顔面領域の 骨接合を容易にするため, 20 種類以上の異なった形態が 用意され，さらに 2 head, 3 head のプライヤーによって 多彩な形態に屈曲適合することが可能である。また，動 力学的接続合性が低く, 衝撃エネルギーを吸収しやすい 特徵を有する ${ }^{814)}$. Leibinger Würzburg Titanium Miniplate System では, 引張強度 $390 \sim 450$ Newton $/ \mathrm{mm}$, 破断伸び $22 \%$, 引張強度 105,000 Newton/mm である. 近年頭蓋形成にも使用されているが，通常の閉頭時の固 定や，比較的単純な陥没骨折の整復には鋼線による固定 で十分である，しかし，頭蓋骨陷没骨折，特に骨片が多 数となった例においては，骨片のゆがみ，骨片が粉砕し てしまうことによる骨量の減少等があるため通常の固定 では外観に凹凸を生じたり，十分な強度が得られない場 合がある.今回，チタンミニプレートを用い，十分な強 度と良好な骨面の形成を得ることができた。使用に際し て注意を要する点としては, 側頭骨では骨が薄いので, 最も短い $2 \mathrm{~mm}$ のスクリューを用いても，スクリューが 一部骨片の内側に突出するため, それをダイヤモンドド リル等で削る必要があることであろう。また，金属片で あるためCT, MRI でアーチファクトを生ずるが，その 程度はわずかであり，頭蓋内病変の読影に特に支障はき たさない.

チタン (Ti) は1796 年に発見され, 45 年以上にわたつ て移植材料として口腔外科, 形成外科領域で使用されて いる1).また, 脳神経外科領域においても, チタンプレー ト，あるいは，チタンメッシュといった形状にて頭蓋骨 形成に用いられている779). 長期間の使用例でも, 周囲組 織に対する影響はほとんどないとされている。チタンは, もともと化学的には活性な金属であり，その活性のため に表面に緻密な不動態皮膜が形成され，優れた耐蝕性を 示す.チタンは生体との適合性がよく, 骨細胞と結合す るといわれる。しかしチタンといえども体液中に溶出す
る.チタンインプラントの周囲のチタンの濃度が高く なった部分の組織は黒ずんでいるが，これは組織の中に 黒い色素が多くなるためで，この色素は 70\% Ti，20\% $\mathrm{Fe}$ であるといわれる。これらが周囲の組織に悪影響を及 涩しているわけでもなく, 特に有害ではないのではない かというのが現在の考方方であるが4), 文献上ではチ夕 ン粉塵による肉芽腫性変化もみられておりり吕, 今後さら に長期にわたる継続的な経過観察が必要であろう.

\section{まとめ}

Titanium miniplate system を多数の骨片となった頭 蓋骨陥没骨折の修復に応用し，良好な結果を得たので報 告した。術後プレート周囲の炎症反応もなく，また術後 のCT, MRI でのアーチファクトも少なく, 読影に支障 はなかった。

\section{文 献}

1) Blake BG, MacFarlane MR, Hinton JW : Titanium in reconstructive surgery of the skull and face. $\mathrm{Br} J$ Plast Surg 43:528-535, 1990.

2) 藤本久夫, 岩坪玲子, 猿田真士, 稜真一郎, 村山高章 : Titanium miniplate の使用経験。日口外誌 32 : 2617-2618, 1986.

3）後藤昌昭，久保田英明，香月 武：顎顔面骨折に対する プレートの応用。耳鼻と臨床 34:1136-1139, 1988.

4) 浜中人士：生体用金属材料。医器学 60:498-505, 1990.

5) Hidalgo DA: Titanium miniplate fixation in free mandible reconstruction. Ann Plast Surg 23:498 $-507,1989$.

6）兵東 嚴, 奥村康明, 中田隆明, 恩田芳朗, 米本武史, 大埜間勉, 西脇孝彦, 奥富 直, 立松憲親, 岡 伸光： シャンピーミニプレートを用いた Buckley-Terry 法に

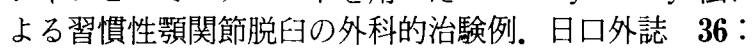
2596-2603, 1990.

7) Joffe JM, Aghabeigi B, Davies EH, Harris M : A retrospective study of 66 titanium cranioplasties. $\mathrm{Br} J$ Oral Maxillofac Surg 31:144-148, 1993.

8) 竹島 浩, 坂本栄一, 嶋田 淳, 平沼康彦, 亀山達也, 向語 彰, 加藤一彦, 山本美朗, 角田豊作: ミニプレー 卜による骨接合の構造力学的研究. 口科誌 37 ： 1299-1300, 1988.

9) Malis LI: Titanium mesh and acrylic cranioplasty. Neurosurgery $25: 351-355,1989$.

10) 三原 学, 前田早苗, 丹下和久, 岩田博行: Würzburg Titanium Miniplate System を用いた顎顔面骨折の 60 例。口科誌 $38: 801,1989$.

11) 三原 学, 丹下和久, 岩田博行, 前田早苗, 伊藤 昇： Würzburg Titanium Miniplate System を用いた顎, 顔 面骨折手術例の検討. 口科誌 $38: 1195,1989$.

12）宮本博文, 浜村康司, 古郷幹彦, 久保茂正, 藤本佳之, 西尾純太郎, 松矢篤三: Würzburg titanium miniplate system の使用経験。日口外誌 $\mathbf{3 4}: 189 ， 1988$.

13) Redline S, Barna B, Tomashefski JF Jr, Abraham 
JL : Granulomatous disease associated with pulmonary deposition of titanium. $\mathrm{Br} J$ Ind $\mathrm{Med} \quad 43: 652$ $-656,1986$.

14）坂本栄一，向後 彰：種々のミニプレートによる骨接合 時の動力学的研究. 口科誌 $37: 1300,1988$.

15）坂下英明，宮田 勝，東野純也：䪽顔面骨折に対するミ ニプレートの使用経験。口科誌 32：1194-1195，1989.
16）佐竹 究, 田中康夫, 鈴木雅一, 伊藤博喜, 井上庸夫, 中川美紀, 時田信博：チタンミニプレートによる前顎部 骨欠損の修復。日鼻科会誌 $28: 173,1989$.

17）嶋田 淳, 李 陽一, 沖津光久, 中西 徹, 江場光芳, 山本美朗, 角田豊作, 田代忠正：チタニウムミニプレー トにより眼窩底即時再建を施行した上顎癌の 1 例. 日口 外誌 $34: 2889,1988$.

要

旨

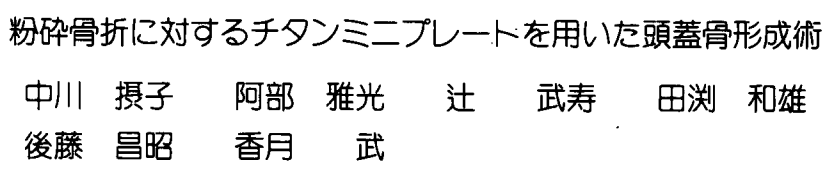

陌没骨折の整復には, 通常鋼線が使用される. しかし, 多数の骨片よりなる複雑な陣没骨折の場合, 骨片の歪み, 粉砕による骨量の隇少のため, 通常の鋼線による固定では, 外観に凹ひを生したたり, 十 分な強度が得られない場合がある. 今回われわれは, 多数の骨片よりなつた複稚な楩没骨折の 2 症例 に対して, チタンミニプレートを用い良好な頭蓋骨形成が得られたので報告した. 術後プレート周用 の炎症反応もなく, また, 術後の CT, MRIでのアーチフアフトも少なく, 読影に支障はなかつた. 